\title{
FUNCTIONS AND MEANINGS OF THE EGG DETERMINATIVE IN THE EGYPTIAN WRITING SYSTEM
}

\author{
Mohamed G. RASHED ${ }^{\text {i }}$
}

\begin{abstract}
${ }^{1}$ :
The attestations of the hieroglyph 'egg sign' in the Ancient Egyptian writing system reveals many of its significant functions and meanings. Often, there is a specific significance that is adapted for the egg sign in words, where it is attested as an ideogram, determinative or as a phonetic complement. In this paper, I wish to assess and collect the Ancient Egyptian words where the egg sign is attested. I will then classify and interpret the functions and meanings of the egg sign within these words. The egg is used as an ideogram and/or signifier for Isis as well as other Ancient Egyptian Goddesses. There are several other uses of the egg sign in the writing system, for example, the egg sign is attested as a determinative in words that share some of the significance or features of an egg. This may return to physical, physiological, mythological or cosmological connections with the egg. These multiple uses and meanings explain the numerous metaphoric connections of the egg, which will be examined further throughout this article.
\end{abstract}

The hieroglyph of the egg $O$ has several values, functions and meanings which appear in its uses in the Ancient Egyptian writing system. It is attested as a determinative, phonetic complement, ideogram, or a signifier. The functions and meanings of the egg sign are significant and it is the aim of the author to study and discuss the egg sign's significance, within this article. ${ }^{2}$ It is noted that the hieroglyph of the egg is also a determinative in various Ancient Egyptian words, that do not mean 'egg' or any of its semantic derivatives. It is noted also that there are some other hieroglyphs, which occasionally replace or are replaced with the egg sign as a determinative in the writing system. Those hieroglyphs are the sun disk, circle sign, pupil, and other circle/oval shaped signs. ${ }^{3}$ The use of the egg sign as a determinative reveals some of the attached significance of the egg. This paper discusses the particular connections and expected associations of these words with the egg, its metaphor, and its symbolic significance. The Ancient Egyptian sources present numerous words, which are frequently or occasionally determined with the ideogram 'egg sign'. ${ }^{4}$ The study of these words in the writing system point out that the egg sign occurs often as a determinative under two main themes. First, it determines words sharing similar cosmological or mythical significance of the egg. Second, it occurs in words sharing its physical or physiological features and shape, where it is mostly attested as alternative determinative in such cases. The Ancient Egyptian words and their attestations under the two themes are classified, dealt and discussed hereafter. It is important to note that the uses of the egg sign include, also, its use as an ideogram and/or signifier for goddess Isis from the Coffin Texts, ${ }^{5}$ and then generally as a

\footnotetext{
' Egyptian Museum, Ministry of Antiquities, (Egypt)
} 
determinative in the writing of the names and epithets of the Goddesses from the New Kingdom onward. ${ }^{6}$

\section{THE USE OF THE EGG SIGN REGARDING ITS SHAPE AND PHYSICAL SIMILARITIES}

The listed words, in this section, mostly are human body organs, medical terms and medicaments, etc.. Therefore, the connection with the egg sign is relied on the assimilated physiological and sexual aspects and their assimilated forms.

\section{a. Human body organs}

It is noted that some of the words which indicate humankind or human organs may include the egg sign. Perhaps, it is because of the resemblance between the egg and the womb in giving birth. Therefore, the words which indicate the sexual organs of both genders are more commonly determined with the egg determinative in association with their fertile aspects. It must be noted that the association with the sexual organs also calls on the mythical significance of the egg, which appears frequently in the textual sources

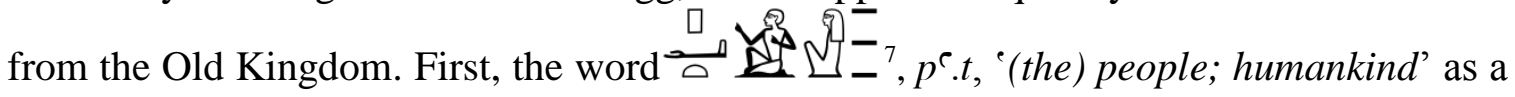
general term defining mankind, occasionally includes the egg sign from the Middle and

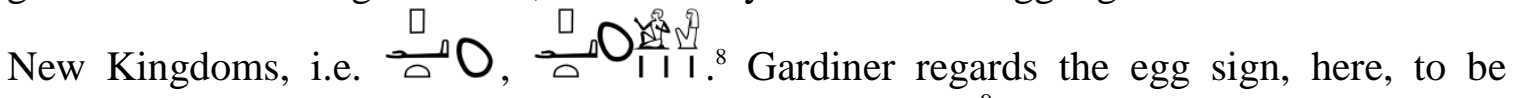
probably derived from an earlier sign for a clod of earth. ${ }^{9}$ It may be interpreted through the cosmological significance of the egg as the origin of the cosmos. The human is considered mythically to be given birth from an egg, i.e., CT 167f/176k, and later in the text of Philae; ${ }^{10}$ the god knots the seeds inside the egg in the womb of the mother, which explains its adapted use here. We can therefore surmise that the egg sign was used as a determinative in words which identify the organs or parts of the human body; especially the sexual organs, but also other organs in oval form. For example the sign occurs within

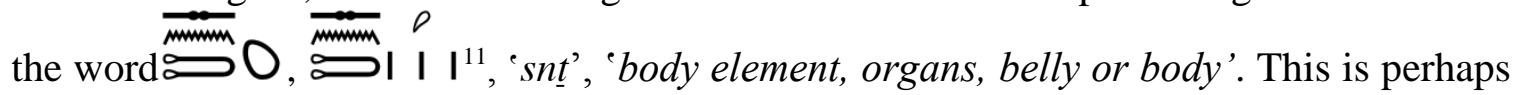
because of the physical form of the belly, probably of the pregnant woman in particular, but also because of the similarity of the signs in hieroglyphs and in hieratic. Physically, the embryo is held inside the womb in the belly, while mythically, he is located inside an egg in the womb. ${ }^{12}$ As has been noted, the egg resembles the womb, but it may also be seen to share the phallus and its sexual attributes. Some words that identify the female or male fertility organs, include the egg sign due to their similarities - which are reflected also in the mythical significance of the egg, such as: the word, which indicates male sexual part(s), $10^{13}$ 'wrm.t', 'a part of the body (testicles (?))'. ${ }^{14}$ It is suggested that the two egg signs probably resemble the two testicles. Among other terms used for the male sexual organ is the word sign in addition to the hieroglyph for the male organ. Perhaps that is explained by its mythical symbol for sexual and reproduction, which guarantees eternity, since it appears in textual sequence with this significance, such as BD 39: ' $z b(n) . n . k$ bnn.k n- ${ }^{2} . t$ ' 'You are forever, (as long as) your phallus stumble'. ${ }^{16}$ 
A significant scene, which reveals this connection between the egg and the phallus, appears clearly on a fragment of a magical stela acquired by the Bibliothèque Humaniste et Municipale at Sélestat. ${ }^{17}$ The magical representations of this stela showing the god Ptah represented in a primeval god cryptogram: a human-headed scarab standing on a shen ring, wearing the atef crown, faces right while his phallus has a large egg on its front top. The accompanying inscription reads 'Pth h hpr $\underline{d}$ s.f' 'Ptah, who developed from himself. ${ }^{18}$ Cosmologically, the egg is associated with the primeval creator god, Ptah, and Amun, etc., and in several texts, the significance of this magical representation may be clearly seen. Physiologically, the reproductive fertility and making the female pregnant are the function of the phallus, while the egg metaphorically gathered the functions of both male and female. It appears clearly in several mythical texts that show the connection between the egg and the phallus. So the creator god impregnates and/or creates the creatures, when he knots the seed in the egg(s). A passage in the Amun hymn Leiden I 350 (II,27), which identifies Amun as a creator and primeval god, reads: ' $t 3 z$ z $m 3 y$ (.t).f $h n^{\top} \underline{d}$ t.f $r$ shpr swh.t.f $m$-hnnw št3w' 'who knots his seed with his body to make his egg develop in secret.' ${ }^{19}$ It also means that he may knot the seeds inside his body which explains the self-creating and reproduction power without a female partner. Another passage of the same hymn provides more explanation (IV, 10-11), reads: 'ohne dass es seine Mutter gab, die seinen Namen schuf, ohne seinen Vater, der ihn schuf, sagend 'ich bin er' (nb(y) swh.t.f ds.f) der sein Ei selbest bildete, Macht, geheimnisvoll an Gestalt, der seine Schoenheit erzeugte, goettlicher Gott, der sich selbst schuf. ${ }^{20}$ In the Khonsu cosmogony at Karnak, a GrecoRoman text reads 'Amun was [..] first in that his name of Ptah, called Ptah who created the eggs which went forth from Nun [...] as Ptah-Tenen who created heaven and earth. He ejaculated at this place in the lake, who created in Tjennet, so that it (the eggs) might be engendered through him like those (things) which came into existence out of it in the district around Hermopolis. ${ }^{21}$ There are several other texts that reveal these metaphoric connections and relationship between the egg and the phallus.

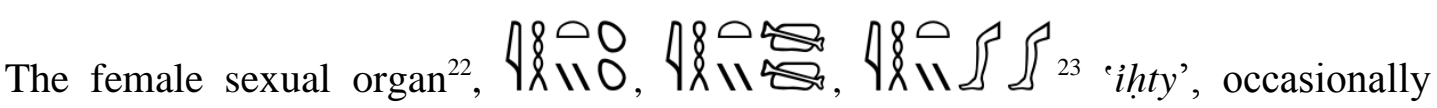
occurs with the egg sign as a determinative. This word identifies the inner parts of the female thighs, which are associated with the birth-giving. ${ }^{24}$ Perhaps it occurs occasionally as alternative term for ' $k$ 3.t' 'womb', which share the some functions and metaphoric aspects with the egg. It occurs as well from time to time with some other words in the medical texts but particularly in reference to some of the body-organs. The word

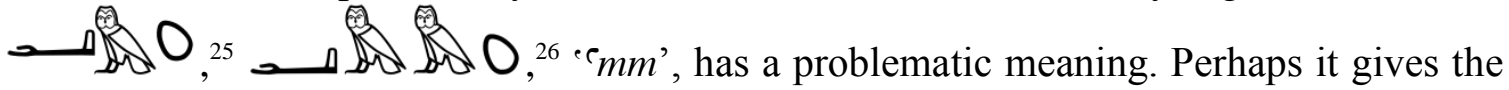
meaning of 'some part of an animal, bird, fish', or 'brain', 'otolith (a calcareous shell-

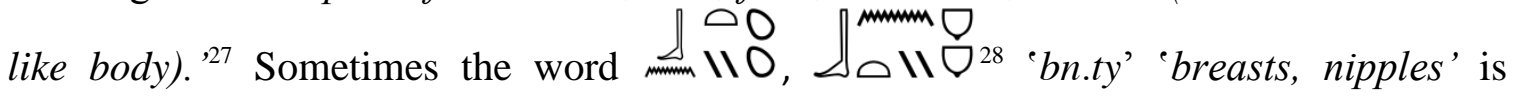

determined with the egg sign instead of the ideogram for breast $\square .{ }^{29}$ The breasts' round form as well as their sexual significance and function have a metaphorical assimilation with the egg. The significance in the connections of the human organs with the egg may be revealed through particular examples in the cases of the terms, ' $w \underline{d} 3 . t$ ' for the 'Wedjat

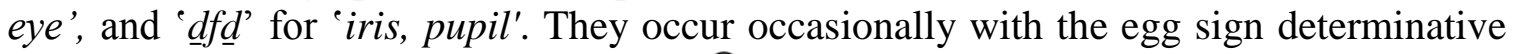
from the Greco-Roman Period, i.e. 


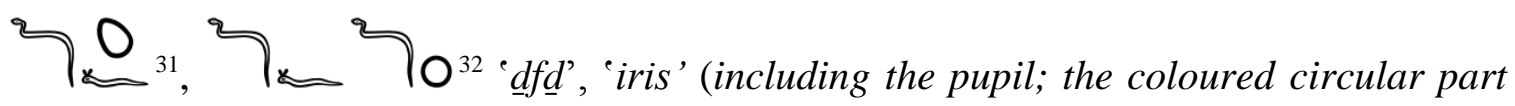
of an eye surrounding the black pupil, the central part). Regarding the use of the egg sign

as a determinative for the pupil or iris, it is noted that the circular pupil sign $\mathrm{O}^{33}$ appears first as a determinative sign in the word 'swh.t' for ' $\mathrm{egg}$ ' from the PT. ${ }^{34}$ The pupil and the eye meet in their circular shape. ${ }^{35}$ The eye of Atum and the eye of Re are both associated with the creation accounts as early as the Coffin Texts, for example, /e.g., in CT 76. The egg determinative is also associated with the same metaphoric and mythical associations as the sun disk. The eye and pupil are connected metaphorically with the sun-disk as well, since the sun gives light, as well as responsible for optical power or vision. In the cosmological context, the egg also brings light in the form of the creator god, who hatches his egg in the first occasion. Apropos of a unique $w \underline{d} 3 t$ eye, on a rectangular plaque in Louvre, ${ }^{36}$ probably used as a talisman in magical practices, in which the pupil appears to be the primordial egg. ${ }^{37}$ The metaphors of the egg and pupil and their mythical connections explain the meanings and values of the egg-shaped of the pupil in this plaque. Mythically, some human organs or parts are described in the form of an egg, which reveals the mythical significance of the egg sign in the writing of the aforementioned terms of human organs. For example, in the Book of the Dead, the deceased's buttocks, breasts or eye sockets are made of carnelian in the form of eggs;

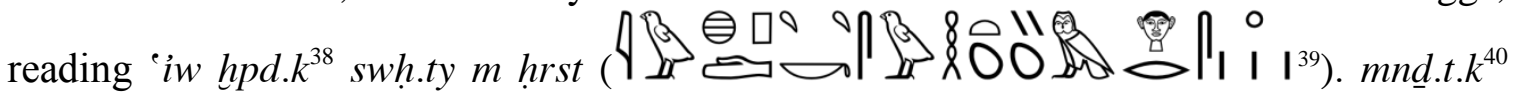
swh.ty $m$ hrst drf(.tn) Hr.w $m$ hssbd'. 'Your buttocks are the two eggs of carnelian. Your eye sockets (?/ breasts) are the two eggs of carnelian which Horus has striped with lapis lazuli. ${ }^{41}$

\section{b. Medicaments and diseases}

The Egyptian medical sources reveal many attestations for the egg sign as determinatives in relevant words such as medications, preparations or medical doses, and disease substances. It has been noted that fresh eggs entered into the composition of certain medicaments, ${ }^{42}$ and were mentioned as part of some medical preparations and prescriptions that are attested clearly in sources such as the Ebers medical papyrus. ${ }^{43}$ The

egg sign may also replace the determinative pustule-sign $\varnothing^{44}$ in terms for certain diseases. $^{45}$ It appears in several words as a determinative for bodily growths or

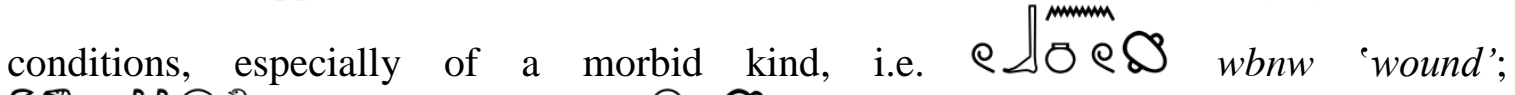

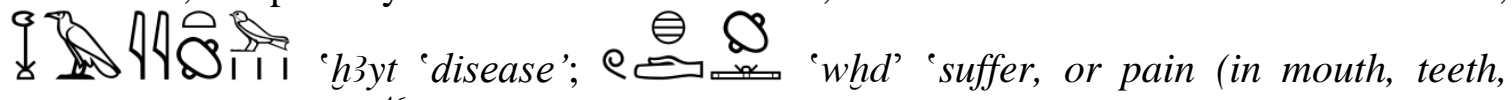
chest, stomach, etc.).' 46

On the other hand, the egg sign is included in the meaning of 'container,' or refers to things containing something inside, whether a medicament (i.e. '?gy.t') or disease substance like 'abscess', which matches the egg's form as a germ cell for the embryo. Perhaps, that explains its particular as a determinative in many medicaments and medical terms. The word $\bigcirc \circ, \diamond \mathrm{O}^{47}$ e $3 . t$ ', 'swelling, tumor, ' which has numerous attestations in the singular or plural, ${ }^{48}$ i.e., in diagnoses, the 'body pain substance' '? $3 . t$ t $w h d w{ }^{49}$ The 


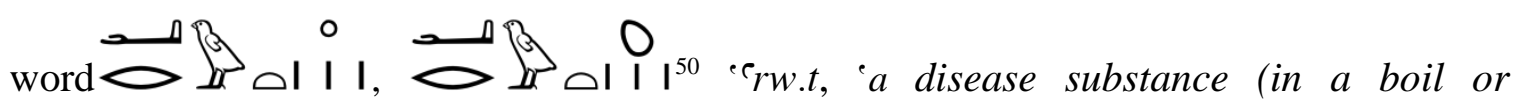
tumor), ${ }^{51}$ occurs as a diagnosis for a disease substance through its appearance. ${ }^{52}$ Another

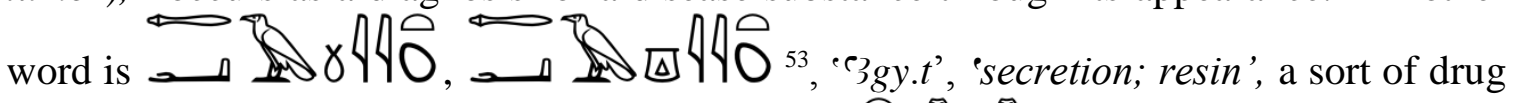
(probably, from the oak tree), also the word ${ }^{54}$ 'tmm', 'to close (a wound) ${ }^{55}$, is attested in the medical and magical texts ${ }^{56}$ in reference to healing through wounding the wounds. Some other words, such as:

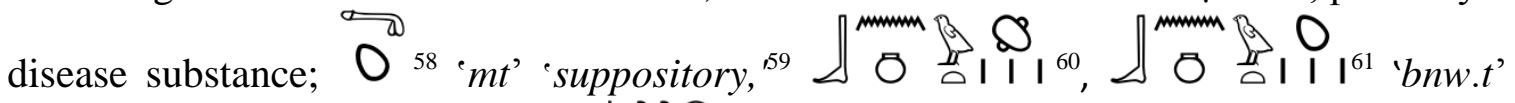
'sore, abscess, boil'. ${ }^{62}$ The word $\downarrow \$ 10$, , 'wd ${ }^{\top} y . t^{63}$, 'molluscan animal' or 'freshwater mussel or clam, ${ }^{64}$ mostly for medical use, but also as food. ${ }^{65}$ Perhaps, the previous examples assert its use as a replacement for the proper determinative sign $\varnothing$ in these words. Another interesting word is $0^{66}$ ' $\mathrm{im}$ ', 'clay or mud'. It mostly occurs in medical texts ${ }^{67}$ as well as in other textual sequences from the Middle Kingdom ${ }^{68}$ onwards. This term was probably used for magical medicinal use, as to form a piece of clay in the form of a statue, figurine, or an egg that a magical spell must be placed upon. ${ }^{69}$

\section{c. Plants or kinds of Food}

A few words for some food types or plants with the egg sign determinative, such as: ${ }_{\triangle} \mathrm{O}^{70}$ ' $p^{\ulcorner} . t$ ' 'a kind of bread or pastry' from the Middle and New Kingdoms. It's not clear whether the food contains an egg in its preparation or not (?). $\left.\right|^{0}\left\{0^{71}\right.$ 'str', 'a sweet-smelling plant', which may be of the 'green plant', reference to a specific or some general plant(?) from the Greco-Roman Period. The egg sign occurs occasionally in a miswriting affiliated with the hieratic writing, ${ }^{73}$ which may

appear in the word in affiliation with the hieroglyph 0 'a seed or grain'. Otherwise, it occurs in relative to its shape as a container.

\section{d. Egg-shaped objects}

Some of the words are sharing the physical forms and aspects of the egg contain the egg determinative, such as 0 as a variation of $11^{74}$ 'imy' inside (a plant or animal), located inside'. ${ }^{75}$ This preparation was abbreviated in its variation (25) or $\mathrm{O}$ 'imy', from the Middle and New Kingdoms, in metaphoric assimilation with the egg with an embryo inside. ${ }^{76}$

\footnotetext{
- 66 - Functions And Meanings Of The Egg Determinative In The Egyptian Writing System
} 


\section{THE MYTHICAL AND COSMOGONIC SIGNIFICANCE AND USES OF THE EGG SIGN}

Some cosmological and mythical Egyptian terms are associated with the egg and its cosmogonic or mythical significance. These words are attested occasionally with the egg determinative which must reflect these significant associations.

\section{a. The cosmogony and creation}

The egg determinative is used within words regarding their association with the cosmogonic and primeval aspects of the egg. E.g., the word 800 , ${ }^{77}$ ' $n$ h.t. ', the flood waters', is attested with this meaning in $\mathrm{BD} 110 .^{78}$ It indicates the flood waters in the fourth Nome of Lower Egypt, where it is mentioned in this spell, among other secret regions. ${ }^{79}$ Also, the word $\int \mathrm{O}^{80}$ 'bnnt' is a word that has been used in the Ancient Egyptian cosmogony to describe a definite place within Nun in which there is a specific substance that was formed by the process of creation, taken from texts from the temples of Edfu ${ }^{81}$ and Khonsu ${ }^{82}$. Reymond ${ }^{83}$ defined 'bnnt,' according to its attestations, to be the essential matter of the creation of the elements, from this bnnt the most terrestrial substance was believed to have evolved. The bnnt was regarded in the Ancient Egyptian cosmogony as the embryo of the earth ' $t 3$ '. It is the seed of the created earth in the late creation legends in Edfu. It is associated with the primeval egg, as a primeval substance in which the creation proceeded, and as a cosmos and germ cell or place of an embryo; a metaphor for the creator god.

\section{b. Toponym 'place name of Gebelein'}

The egg sign occurs also as a determinative in toponym and place names in another significant association. It is attested as a determinative in the word ${ }^{84}$ 'inr.ty', a place name that is associated with the god Thoth as his arising place. The egg sign appears even earlier than the Old Kingdom in a variation of the word in PT $534^{85}$ : $\gamma_{0} 00 S_{86}$ 'intwy', 'Gebelein'. The association of Thoth with the region of Gebelein in Upper Egypt is clear, ${ }^{87}$ since Gebelein was called ${ }^{\prime}$ inr.ty ${ }^{\prime 88}$, a name that has some of its variations written with the two eggs signs: 189 'inr.ty, which occurs sometimes instead of the two rocks in its original writing as a place of worship of the Goddess Hathor and the God Thoth, so that both deities sometimes bear the epithet $\smile 0$ ' $n b(. t)$ inr.ty' ${ }^{\prime 90}$ 'Lord/Lady of Gebelein. '91 'inrty' means literally 'the town of the two rocks', the name of Gebelein, with its dual meanings, remains also in its current Arabic name. Gardiner mentioned that the epithet here, which means 'lord of the two eggshells, ${ }^{, 92}$ refers to the town of Gebelein. ${ }^{93}$ The previously discussed variations refer to the region of Gebelein in particular, while it also occurs as an epithet of Thoth, but in connection with his place of worship, not his eggs. ${ }^{94}$ However, there is no proof to suggest a connection between Gebelein and the egg, which may 
explain the use of the egg sign in its writing. This requires more research in the relevant significance and mythical roles of the egg and Gebelein. I may suggest a connection regarding the background of Gebelein as a famous quarry for stone, which is reflected in its name 'town of the two rocks.' As pointed out below, words meaning 'stone material' contain the egg as a determinative. Symbolically, some of these stone objects were said to have been made of eggshell. This may have been suggested, in the religious or mythical texts, in order to give the object the symbolical value of the egg.

\section{c. Stone materials}

Several terms for rocks, stone material or precious stones contain the egg determinative in some of their frequent attestations. I.e. $\square \square, \triangle 0^{95}$ 'e3.t', 'precious stone or material', for metal or stone material, which occurs sometimes with the egg sign. ${ }^{96}$ Therefore, this word may occur in some composed terms for vessels, containers (with $n$ genitive); as well as for sculpture, statues, deposits of stone. ${ }^{97}$ Another word is $\neq 100$ 98, 'swti.t' meaning 'pearl' or also in the meaning of 'little bead' made of carnelian. Another word is ' $h r s t^{\prime 99}$, it has the meaning of 'carnelian, or beads made of carnelian,' and it is used with the stone, circle-shaped or egg determinative. As a material for beads beside the 'hrs.t carnelian', it also appears in the word ${ }^{0} \mathrm{l}^{\mathrm{I}} \mathrm{I}^{100}$ 'dr.t.t', 'precious stone' for beads. Though there is no certain proof to explain the use of the egg sign as a determinative for stones and stone material, the egg shell was utilized to make vessels ${ }^{101}$ as well as stone material. Its yolk was utilized to obtain color effects in fine metal work and pigments. ${ }^{102}$ The egg itself was described in some texts under the 'golden egg.' So, the egg sign probably gives some of the symbolic significance of the egg to sacred or religious objects or things made of these materials. An interpretation may clarify this association in the case of the above word 'carnelian'. First the association between the pearl and the egg in its significant meaning of ' $w o m b$ ' has already been pointed out. The carnelian is associated with the blood and womb in its red color, while it is similar in shape to the egg. In his study of the Tit-knot, Westendorf ${ }^{103}$ referred to the word 'swr. $t^{104}$, as an earlier variation of $\neq 100$ 'swti' ${ }^{105}$, which has the meaning of 'pearl, 'or 'beads' especially that made of 'hrs.t' carnelian. He also pointed that the word $\neq 100$ 'swt.i.t $t^{106}$ 'pearl or 'beads from carnelian', following in the Berlin dictionary, under the same inventory, the word $\neq$ a ${ }^{107}$ 'swti' occurs from the PT, and means 'be large, or grow up.' In the sequence of this significance, Westendorf indicates an interesting amulet, which has a magical significance, namely to let the child grow inside his mother's womb (mythically, inside the egg too). ${ }^{108}$ Perhaps, that gives a part of the significant use of the egg sign as a determinative here. In this sequence, it may be interesting to compare that with what has been mentioned about the body organs. According to some mythical texts, ${ }^{109}$ some organs were made of carnelian in the form of an egg. It must be pointed out that the use of the egg determinative in stone material terms reflects its mythical and physiological significance. Therefore, the magical recitations and their performances reveal the use of clay models of egg in some magical rites, which is seen in the Papyrus Harris and other magical sources. ${ }^{110}$ 


\section{d. Cloth}

Beside the skirt or garment 'swh' 'the loincloth, apron', which is associated phonetically with the 'swh.t' egg, as has been noted. There are some other sorts of fabric and cloth pieces, which have their Ancient Egyptian given names, occasionally, with the egg sign, i.e.: or gilded), or sheath', attested from the PT. ${ }^{112}$ It gives the significance of 'a (protective)

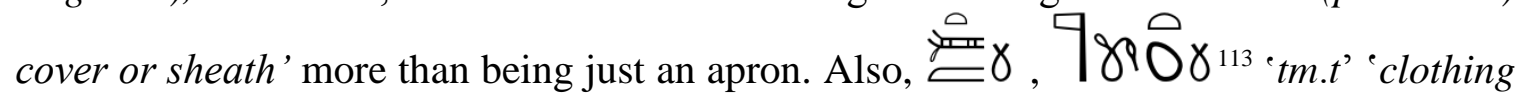
fabric', a sort of cloth fabric or material that was used in the mummy wrapping for Osiris or the deceased, which is attested in the texts of Dendara from the Greco-Roman period. Another word attested with a similar meaning is mmm $44 O^{114}$, 'nj.t', 'wailer, a female mourner's suit'. As a material for neck-pendants, occurs the word 1 O 'sti'. ${ }^{115}$ It may be observed here that these sorts of fabric or clothes mostly have mythical significance in funeral ritual and mummy wrappings associated with the rebirth and birth. That may explain the significance of the egg determinative in such use, which is to give its mythical significance to the person who wears them.

\section{CONCLUSION:}

The egg sign is attested as a determinative in words that share some of the significance or features of the egg. Whether these words are associated physically and physiologically, or they reveal mythological and cosmological connections, it always has an adapted meaning. It has been noted that the egg sign is used, mostly, in words classified as: medicaments and medical terms, human organs, materials, and words that have cosmogonic or mythical significance, or even to replace signs regarding their oval and circular shapes. These uses are counted in addition to its use as an ideogram for goddesses. Finally, it is noted that the wide metaphor of the egg in the Egyptian myth and cosmogony is extended into the Egyptian writing system, where the egg sign has wide, rich functions and meanings. 


\section{NOTES:}

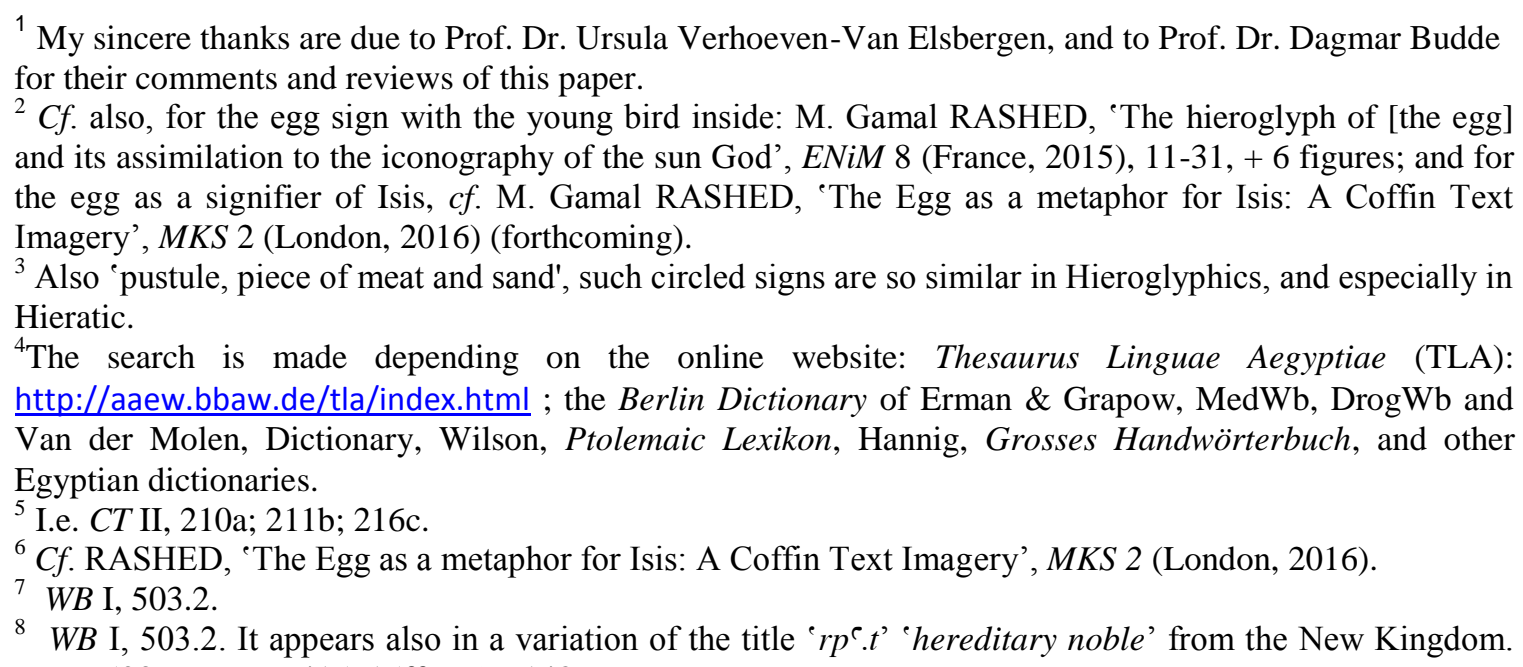
$W B$ I, 503.9; WB II, 415, 15ff; FCD 148.

${ }^{9}$ A. Gardiner, Egyptian Grammar (London, 1950), 474. It has been noted already that the egg sign may replace, wrongly, the clod of earth sign, and vice versa, although I may regard that for another probable interpretation, since the two signs share similar significance in the origin of creation myth in various legends.

${ }^{10}$ Philä II, 181, 2-3.

${ }^{11}$ WB IV, 180.1. A piece of meat or egg sign determinative is used. Its attestations in the Book of the Dead indicate the body organs: $\mathrm{Tb} 161$ 'the bones are scattered. They are scattered, his skeleton (zš.sn snt.t.f)'. The Online website TLA: B. Backes, Totenbuch-Projekt, Ägyptologisches Seminar der Universität Bonn; cf. P. Paris Louvre 3092 + Fragment. Montpellier (P. Neferubenef), Tb 161.

${ }^{12}$ The vignettes and scenes depicting the daily birth of the sun God, present some notable representations of the pregnant Goddess and her womb. The shape of the womb is taking the shape of an egg, which is asserted with the accompanying texts that sometimes describe the god inside his egg. The first scene of the first hour of the book of the Day presents a good example. Cf. A. Piankoff, The Tomb of Ramsesses VI, Texts, I, Bollingen Series XL.1389 and fig. 130; Müller-Roth, Buch vom Tage, OBO 236 (Freiburg, 2008), 70ff, Abb. 13 and Taf. I, XVII, XXII and XXIII.

${ }^{13}$ WB I, 333.4; Urk. IV, 389.11; 506.16; R. Hannig, Grosses Handwörterbuch Ägyptisch-Deutsch (Mainz, 1995), 205, its meaning of testicles (?), the two round male sex organs which produce sperm.

${ }^{14}$ Grundriss der Medizin I, 85f, gives the Ancient Egyptian terms for the male and female sexual organs. There are several words that refer to the phallus, but in the medical expressions, we know only ' $h n n$ '. Ebers papyrus describes the testicles: 'they are two $m$ t bowls for the hrwj testicles'. Ebers 100,7.

${ }^{15}$ WB I, 460.7; Baines, Orientalia 39 (1970), 398, n.2 'Phallus'(?).

${ }^{16}$ TB 39 (Papyrus of Turin 1791); cf. TLA online: B. Backes, Totenbuch-Projekt, Ägyptologisches Seminar der Universität Bonn (' $z b(n) . n=k b n n=k n-\underline{d}, t$ ' 'Auf ewig bist du, (genauer) dein Phallus, gestrauchelt'); other similar recitations that assert the role of the phallus and its importance for life such as: PT. 1061; 510.

17 E. Graefe, 'Phallus und Ei: Ptah als Urgott, Das fragment einer magischen stele der Bibliothèque Humaniste et Municipale de Sélestat,' in: W. Clarysse, A. Schoors, H. Willem (eds.), Egyptian Religion: The last thousand years, I, Studies Dedicated to the Memory of Jan Quaegebeur, OLA 84 (Leuven, 1998), 117-124ff, pl. I.

${ }^{18}$ Graefe, OLA 84, 120, pl. I.

${ }^{19}$ Cf. J. Zandee, 'De hymnen aan Amon van papyrus Leiden I 350', OMRO 28 (Leiden, 1947), pl. II.

${ }^{20}$ Zandee, OMRO 28, pl. VI.

${ }^{21}$ This inscription is written above Ptah, E. Cruz-Uribe, 'The Khonsu Cosmogony', JARCE 31 (Cairo, 1994), 173. 
${ }^{22}$ WB V, 93,12-94,2; Grundriss der Medizin I, 87ff; VII, 894f. The female vulva was named ' $k 3 . t$ ', the term attested frequently in the medical texts with the male phallus $h n n$. Also in other religious texts, such as the book of Himmelkuh, describe the birth of the sun god from the vulva of the sky Goddess.

${ }^{23}$ WB I, 120,16-17; P.Berlin 3050, 3,4; Edfou I, 150. Compare also with 'ih.ty' 'throat' (WB I, 123.2bis), a variation of 'hty.t' 'throat' (WB III, 181.4-16; FCD 179; R. Van der Molen, A Hieroglyphic Dictionary of Egyptian Coffin Texts, PÄ 15 (Leiden, 2000), 361; H. L. Lesko, A Dictionary of Late Egyptian, II (Providence, 2002), 144; P. Wilson, A Ptolemaic Lexikon: A Lexicographical Study of Texts in the Temple of Edfu, OLA 78 (Leuven, 1997), 685.

${ }^{24}$ It has occurred with this meaning since the $P T$, cf. Pyr. 262. It often occurs in association with the sky Goddess or the king's mother.

${ }^{25} W B$ I, 184.24 .

26 WB I, 186.14-15; Drog Wb 95f; Ebers 30,1; 32,3; 63,20; P. Hearst, 13,10; 13.6; E. Iversen, 'Some remarks on the terms', JEA 33 (1947), 47ff.

${ }^{27}$ The meaning of this word is still unclear enough to be judged; Grapow mentioned this word as a probable term for 'brain' but without certain translation: Grundriss der Medizin I, 28 (4). However, Dawson examined this word, suggesting its original meaning in his conclusion to be 'small pebble, shell, or granule', and he disposed the meaning of 'brain', 'roe, egg, or fry fish,' cf. W. R. Dawson, 'Studies in Egyptian Medical Texts', JEA 18 (London, 1932), 150f. On his side Iverson studied its textual occurrences, and approved its meaning to be 'a part which is common to fishes, birds, reptiles, other animals, and human beings, and to be found in the head. He supposed that the meaning 'brain' appears to be a separate meaning for the word. Iversen, JEA 33, 48.

${ }^{28}$ WB I, 457.11-14; FCD 83; Grundriss der Medizin $\mathrm{VII}_{1}, 247 \mathrm{ff}$.

29 I.e: in the Ebers Papyrus (808), referring to the human breasts of both gender, and often in dual. The word 'bn.ty' is not often determined with the egg sign. According to Grundriss der Medizin III, 57ff, it occurs in the meaning of 'Abortion', but Westendorf (in Grundriss der Medizin VII ${ }_{1}, 248$ ) commented: it is derived from bnn 'beads', (cf. WB I, 460.7-13), which functions as a medicament or drug dose, see: Ebers $357^{\text {' }}$.t $n t$ dr šp.t $m$ ir.ti $m$ bnn'; also Ebers 368. For more about 'bnn', cf. Grundriss der Medizin VII, 251.

${ }^{30}$ WB I, 402.1; V, 537.6. For other variations, cf. WB I, 401.12-402.2; Also in 'Irt-Hr' 'Horus-eye' in Edfou (Edfou I, 129, 17; IX, Tf. 21b; LGG I, 432; see also: 'Irt-Hr-w3dt': LGG I, 434) ; 'Irt-nfrt' 'the beautiful eye' in association with Isis ( $L G G$ I, 426; A. Farid, 'New Roman Blocks from a Hypostyle-Hall found at Asfun el-Mata'na', SAK 13 (1986), 41; 'Irt-wrt' 'The great/ big-eye', var. 'Irt-Hr-wrt' (P. Chester Beatty VIII. vrso, 10,4; Vandier, Z̈̈S 93 (1966), 136; LGG I, 425). For the sign as a phonogram and ideogram, cf. Wilson, A Ptolemaic Lexikon, 286f; Kurth, Einführung ins Ptolemäische. I, 168; S. Cauville, Dendara: Le fonds hiéroglyphique au temps de Cléopâtre, 55.

${ }^{31}$ LGG VII, 624; H. Gauthier, Le temple de Kalabchah, I: Texte (Le Caire, 1911), 186, Zl. 2.

${ }^{32}$ WB V, 572.10-573.11; Med Wb 1004; Hoffmann, 'Das Wort $\underline{d} f \underline{d}$ ', GM 132 (1993), 37f; Ebers 345; 854c.

33 Gardiner, Egyptian Grammar, 451. This sign used as a determinative in words that have shared a similar circular form from the Old Kingdom onwards, which explains the adapted use instead of the sun disk, egg, and other similar determinative signs. Gardiner, Egyptian Grammar, 538. The pupil sign occurs as a phonogram for ' $i r$ '; and for the word ' $m t$ ' 'to die'. The two pupil signs gives the phonogram ' $m ; m$;; $m n$; $n m$ '; and in the writing of the words: 'irty' 'both eyes'; ' $m 33$ ' 'to see'; the both pupil-signs are occasionally replaced by the two-egg signs for the same significance. Kurth, Einführung ins Ptolemäische. I, 169 (n. 2425), and references there in; Cauville, Dendara: Le fonds hiéroglyphique au temps de Cléopâtre, 55.

${ }^{34}$ Pyr. 1997; 1968d; 1969c.

${ }^{35}$ They meet mythically as well, the pupil is equated with the sun-disk, e.g., the magical papyrus of Harris IV, 10-V,1. It also equates metaphorically with the disk (Dendara VI, 52,7-9; IX, 120,5). Re creates mankind from his tears ( $\mathrm{Tb} 101)$.

${ }^{36}$ Louvre E 14.240; R.A. Caminos, $L \ddot{A} \mathrm{I}, 1187$ (n. 1).

${ }^{37}$ The sclera of the eye is occupied with an enigmatically composed depiction, which is represented in dualisms: two birds or fowls, two lions and two signs, while the central point of that is the pupil in the form of the egg. Inside the pupil itself, there is a depiction of a child. This depiction was aimed to apply the metaphoric significance and magical power of the egg into the pupil or the Wedjat-eye as a whole. É. Drioton, 'Un Oudja; à représentation Hermopolitaine', RdE 1 (1933), 81ff, fig. 1; G. Roeder, Hermopolis 
1929-1939: Ausgrabungen der Deutschen Hermopolis-Expedition in Hermopolis, Ober- Ägypten (Hildesheim, 1959), 186 (ss.44a).

38 'hpd' means 'hinders,' ends of the body (= buttock(s); rear part). WB III, 270.14-271.3. The word is not attested with the egg determinative.

${ }^{39}$ P.London BM 9900 (P. Nebseni) (1), Tb 172 (line 21, 23); G. Lapp, The Papyrus of Nebseni (BM EA 9900), Catalogue of Books of the Dead in the British Museum III, (London, 2004), pl. 99, line 20-21, and 23.

${ }^{40}$ 'mnd.t', 'chest (of a man or woman)', WB II, 92.11-93.8; MedWb 375f; it also occurs in the meaning of 'eye sockets(?)', cf. WB II, 93.10-14; FCD 110; MedWb 374f. The word is not attested with the egg determinative.

${ }^{41} \mathrm{~Tb}$ (Allen), 172, 3-4; cf. also $T b$ (Hornung) 172, 72.

${ }^{42}$ Grundriss der Medizin VI, 433f; LÄ I, Cols. 1186.

${ }^{43}$ Grundriss der Medizin VI, 433; Ebers 374; 444; 409; 539; 710; 718. The egg yolk and surrounding membrane were known not only as food, but also used for medical purposes. The egg shell was also utilized for medicinal purposes; cf. Grundriss der Medizin VI, 433; Joan P. Alcock, Food in the Ancient World, (Westport, 2006), 75.

${ }^{44}$ A 'pustule or gland': Gardiner, Egyptian Grammar, 539. It appeared as an alternative determinative for some diseases and medical terms. This sign basically occurs in the writing of the word 'wt'. Grundriss der Medizin $\mathrm{VII}_{1}, 226-231 \mathrm{ff}$., which is a binding material, mostly to be used in wounded skin and surface wounds, as well as inside the body organs in some disease cases. Its use appears also in the medicaments and preparations. Medically, the egg white is also used as a binding material in medicaments.

${ }^{45}$ Grundriss der Medizin III, 36, 55, 60.

${ }^{46}$ Cf. Grundriss der Medizin III, 36, 55, 60; compare also its variation, in Gardiner's sign list. Gardiner, Egyptian Grammar, 539f .

${ }^{47}$ WB I, 166.3; Grundriss der Medizin $\mathrm{VII}_{1}, 123-129$; Ebers 870; and its plural ' 3 w.t' Ebers 875; 874a; also with the alternative determinative, Ebers $875 \mathrm{~b}$. Compare also with the word ' $' . t$ ', which refer to a 'body organ, a piece/ part of the body of an animal or human', is often determined with sign, cf. WB I, 166.14-16. It occurs frequently in the medical texts to indicate a disease or pain in a specified body organ; or in plural, probably in reference to the whole body. It also occurred in the Egyptian myth, in which, Khnum fashions the child body's organs in the royal birth. Grundriss der Medizin I, 17f; III, 40.

${ }^{48}$ I.e. in the P. Amherst 14, Instructions of Chati, and many similar texts from the New Kingdom: 'A large ulcer/tumor is on his neck ('3.t wr.t hr nhb.t.f), in which produced by fat'. cf. the online website TLA: P. Dils, Altägyptisches Wörterbuch, Sächsische Akademie der Wissenschaften, Leipzig. A similar occurrence

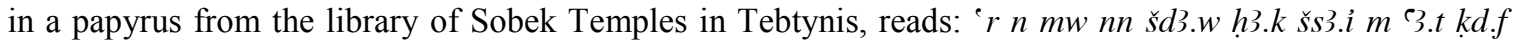
$p n '$ ', 'Recitation of the water: 'There is nothing hidden, back to you, (because) [I] am familiar with a tumor of this kind!' J. Osing, G. Rosati, Papiri Geroglifici e Ieratici da Tebtynis, (Firenze, 1998), 189-215, Tavole $22-23$.

${ }^{49}$ WB I, 356.12. A similar diagnostic expression: ' $3 . t n t$ ' $\underline{d}$ ' (WB I, 239.15) describing 'the Fatty Tumor disease substance'. For more about the '3t- tumors' diagnose, cf. Grundriss der Medizin II, 37; Ebers 863875.

${ }^{50}$ WB I, 210.18-19; Grundriss der Medizin VII 147 f; Ebers 42,15; 104,3; 104,15, 105,18; and Ebers 870c. Probably, it derived from ' $r w^{\prime}$ ', 'to shine(?)', cf. Van der Molen, A Hieroglyphic Dictionary of Egyptian Coffin Texts, 75.

${ }^{51}$ An aside interesting observation, I should mention the phonetic value of ' ${ }^{\top} r, t,{ }^{\prime} r w . t$ ' in comparison with its Arabic parallel. The Arabic term which is used to diagnose or describe a disease substance through its appearance, called: عَرض card' (in singular), and عَرْوض curud' ( in plural). It has the same phonetic in the singular and plural with the Egyptian term, which may be derived from its Ancient Egyptian original.

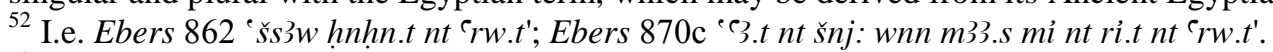

${ }^{53}$ WB I, 168.10-11; Grundriss der Medizin VI, 80f; $\mathrm{VII}_{1}, 134$; Ebers 539. Compare also ' $g$ 3', 'a sort of oil or ointment' that is used in anointing rituals. WB I, 236.2; Koura, Öle, 164; P. New York MMA 35.9.21.

${ }^{54}$ WB V, 308.10-11; Grundriss der Medizin $\mathrm{VII}_{2}$, 953; also with the determinative, Ebers 522.

${ }^{55}$ It derived from the word 'tmm' 'to close, shut, lock (your mouth, your face), not to be inquisitive nor inquiring' ( $W B \mathrm{~V}, 308.5-8)$. 


\footnotetext{
${ }^{56}$ In the New Kingdom magical papyri, P. Berlin P.3027: a magical recitation for the mother and the child, (recitation E, line 4,4): ' $m$ h3.w hr g3b.fy z3w tmm' '(do) not disseminated his upper arms, avoid to embed'.

${ }^{57}$ WB III, 19.1; Berlin Dictionary entered the word as a medical word similar to ' $h 3 w y . t$ ' (III, 18.16), though its specific meaning is unclear. Probably, It derived from the word ' $h 3 w^{\prime}$, 'to increase, excess'. Lesko, Late Egyptian Dictionary, I, 296.

${ }^{58}$ WB II, 167.15-16; Grundriss der Medizin $\mathrm{VII}_{1}, 411$ (as a drug form).

${ }^{59}$ Grundriss der Medizin I, 20f; II, 52 (n.5); III, 23, 31f. Its meaning is unclear, maybe it identifies 'the
} band, core, or to what could be described as a container for blood, tears, etc. Grundriss der Medizin I, $20 \mathrm{f}$. Otherwise, a tub that contains a medical dose may be a possible meaning. Grundriss der Medizin II, 52.

${ }^{60}$ Ebers, 13,7; 13,10; WB I, 458.8-11; Grundriss der Medizin $\mathrm{VII}_{1}, 248$.

${ }^{61}$ Ebers 527 (70,24); Grundriss der Medizin VII, 248.

${ }^{62}$ Grundriss der Medizin $\mathrm{VII}_{1}$, 248f. It is a disease substance that appears on the breasts, female sexual organ, and teeth, etc.. Also the egg sign is a determinative in the word 'p3ys.t an appearance of the wbnwwound, a sort of wound that cannot heal. Grundriss der Medizin $\mathrm{VII}_{1}, 257 f$.

${ }^{63}$ Ebers 119; 165; 182; 496; WB I, 407.7-9; Grundriss der Medizin VI, 147f.; FCD 76; D. Meeks, Mythes et légendes du Delta d'après le papyrus Brooklyn 47.218.84, MIFAO 125 (2006), 150, n. 530, line XV, 9.

${ }^{64}$ Dawson, JEA 18, 153f. The molluscan animal or freshwater clam with its shell. The shell has a physical form similar to the egg; both contain something and can be divided or hatched. Perhaps, it also clarifies the case of the determinative use here, as well as in similar medical term.

${ }^{65}$ Grundriss der Medizin VI, 147f. It has various uses in medicaments as an ointment, binding or formation material in some medical preparations, and eye ointment. For more about its medical use and attestations in the medical texts, cf. Dawson, JEA 18, 153f.

${ }^{66} W B$ I, 78.2-3. Perhaps it derived from 'im' 'form, image, shape' as a noun. WB I, 78.1; FCD 17; see also $W B$ I, 77.16-17.

${ }^{67}$ WB I, 78.3: 'im n twt' 'Clay statue'.

${ }^{68}$ I.e. 'draftsmen filled it with pigment and figures of clay ( $m$ tit $m$ im), renewing what the King of Upper and Lower Egypt, justified, had made'. Louvre C 12; cf. TLA online: R. Landgrafova und P. Dils, Altägyptisches Wörterbuch, Sächsische Akademie der Wissenschaften, Leipzig.

${ }^{69}$ A spell for protection from crocodiles in the magical papyrus of Harris may prove this interpretation. This spell must be read on a clay model of an egg and thrown in the middle of a lake. cf. H. O. Lange, Der Magische Papyrus Harris, (Kobenhaven, 1927), 53f; P. BM EA 10042 VI, 12ff; C. Leitz, Magical and Medical Papyri of the New Kingdom, (London, 1999), 39, pl. 17 (12ff).

${ }^{70}$ WB I, 503.12; FCD 88.

${ }^{71}$ WB IV, 344.3; Wilson, A Ptolemaic Lexikon, 966.

${ }^{72}$ WB I, 344.2.

${ }^{73}$ For miswritten words in the Ptolemaic Roman temples $c f$. C. Thiers, 'Tôd; D. Kurth, 'Einfluss der Kursive', EB 5 (Wiesbaden, 1999), 69-96ff. For other miswritten words containing the egg sign cf. Kurth, $E B$ 5, 91 f.

${ }_{74} W B$ I, 75.20-22. a derived use of the same term 'imy' WB I, 72.13-17, 'to be inside, to be resident/located, what is within.' Its origin/root is the preposition or adverb 'im ' 'there', which refers to a place, WB I, 72.4-8. Also, $C f$. RASHED, ENiM 8, $12 \mathrm{ff}$.

${ }^{75}$ Ebers 56, 11-14. It is attested frequently in the medical texts.

${ }^{76}$ In wordplay with the meaning of 'is located in, what/who is inside. For the variations of 'imy' with the egg sign and its interpretation, cf. $C f$. RASHED, ENiM 8, $12 \mathrm{ff}$.

${ }^{77}$ WB II, 289.19.

${ }^{78}$ P.Turin Museo Egizio $1791 \mathrm{~Tb} 1-113$, Tb 110. Compare also WB II, 289, 17, where this word refers to the Goddess ' $n h . t$ ' whose name attests in the PT; and it refers too to the sun god ' $n h j$ ', who is attested in the BD.

${ }^{79} \mathrm{~Tb}$ (Lepsius), 110.

${ }^{80}$ WB I, 460.8; Edfou IV, 139,11-15; E. Reymond, The Mythical origin of the Egyptian temple, (New York, 1969), 63ff. Compare with the similar derived word 'bnn, Phallus' (discussed above)

${ }^{81}$ Edfou VI, 16, 5-6; IV, 139, 13.

${ }^{82}$ K. Sethe, Amun und die Acht Urgötter von Hermopolis, (Leipzig, 1929), 118f, pl. II, b.5. A text attested in the bark chapel of Khonsu temple, spoke of the attributes and phases of Amun, where Amun was 
equated with the Ba of Nun, the primordial god, the creator who created the seeds: 'he is the bnnt (primordial seed) in Nun who fashioned the bnnt on the First Occasion (bnn b3 pw m nwn bnbn bnnt $m$ sp[tpy])'. D. Mendel, Die Kosmogonischen Inschriften in der Barkenkapelle des Chonstempels von Karnak, MRÉ 9 (2003), 38, 40f, Taf. 3.

${ }^{83}$ Reymond, The mythical origin of the Egyptian temple, 63ff; Idem, CdE 40 (1965), n. (u).

${ }^{84}$ WB I, 98.7.

${ }^{85}$ Pyr. 1271. It reads: 'If Thoth comes with this his evil coming, do not open your arms to him, but let there be said to him his name of 'Motherless'. Go southward to Gebelein (?); go to Pe, to the Abode of Thoth!'. FEPT 201.

${ }^{86} \mathrm{WB}$ I, 102.1. It is interpreted as a variation of ' inr.ty' for 'Gebelein'. Cf. M. A. Stadler, Weiser und Wesir; Studien zu Vorkommen, Rolle und Wesen des Gottes Thot im ägyptischen Totenbuch, ORA 1 (Tübingen, 2009), 158; Zibelius, Agyptische Siedlungen, 193f. Compare also with innrt, 'The innrt serpent', an epithet for deities, which is attested with this determinative sign in the Greco-Roman Period. Edfou IV, 284,4; VII, 269, 7-8; LGG I, 399 f; VII, 269, 3-5 - 269, 7-8.

${ }^{87} B D 134$ indicates the association of Thoth with 'inr.ty', 'the two halves of the eggshell'. It reads: 'D $\underline{h} w t y$ s3 inr pri $m$ inr.ty', 'Thot der sohn des Steins, der hervorgekommen ist aus den beiden Steinen/Eierschalen,..'. Stadler, Weiser und Wesir, 157. The word 'inr.ty' means 'stone', 'eggshell', and 'Gebelein' as a place name. Stadler discussed the meaning of this term and its suggested association with Thoth. He presented the previous interpretations asserted with the various related occurrences. Cf. Stadler, Weiser und Wesir, 157-160.

${ }^{88}$ The name is derived from the word inr, 'stone, rock, block of stone material'. WB I, 97.12-98.6; FCD 23-24; LGG I, 399. The Dictionary of Berlin gives the translation 'The both eggs (?)', from them, Thoth come to exciting', as is attested in Tb (Naville), 134, 9; also Pyr. 1271.

${ }^{89} \mathrm{WB}$ I, 98.8 .

${ }^{90}$ H. Kees, Z̈̈S 71, 150ff; AEO II, 20; LGG III, 586; El Bersheh II, Tf. 7; W.C. Hayes, The burial chamber of the treasurer Sobk-Mosé from Er Rizeikat, (New York, 1939), Tf. 6 (where it is associated with Anubis).

91 L. Habachi, 'Building Activities of Sesostris I in the area to the south of Thebes', MDAIK 31 (1975), 33ff, fig. 4. Hathor was described as 'Hthr nb.t inr.ty' 'the mistress of Anerti' on a boundary stela of Sesostris I, from the great temple of Amun at Karna, where the name of Gebelein was written with the same variation on this stela.

92 The two halves of the eggshell have played an essential role in creation myths from Hermopolis, where the egg is also associated with Thoth, Re, the Ogdoad, etc.. According to the legend the creator god came forth out of his egg in Hermopolis, and the two halves of this sacred eggshell were then buried in Hermopolis. The main source of this legend is known from two inscriptions in the autobiography of the high priest Petosiris from his 26th Dynasty tomb in Tuna el-Gabel. In this inscription, Petosiris states that he protected the land of the bark ( $\breve{s}_{-}(3)$ in Hermopolis because this was the birthplace of the sun god, Re. It is symbolized as the cradle of the gods; the place where everything in being is born; as well as the burial place of the two halves of the egg: ' $g s(. w)$ swh.t krs im.f ( $h n^{\complement}$ hpr.w-n.w im.f)' 'die Halften des Eies sind dort bestattet (zusammen mit allen Wesen darin)'. Cf. G. Lefebvre, Le Tombeau de Petosiris, I, (Le Caire, 1923), 140; Idem, Le Tombeau de Petosiris, II: Le Textes, (Le Caire, 1923), 38f, nr. 62, Line 5, and nr. 81, Line 67; Idem, ASAE 23, 65ff; Roeder, Hermopolis, 165 (ss.6c), 186 (ss.44); Stadler, Weiser und Wesir, 157-160; S. Morenz, 'Das windbefruchtete"Welt-Ei",, in S. Morenz (ed.), Aus Antike und Orient: Festschrift Wilhelm Schubart zum 75. Geburtstag (Leipzig, 1950), 77, 79, 94.

${ }^{93}$ AEO II, 20.

${ }^{94}$ For the significance of the two eggshell halves in the legend of creation and their association with Thoth, cf. Stadler, Weiser und Wesir, 157ff; Roeder, Hermopolis, 186 (ss. 44d).

${ }^{95}$ WB I, 165.13-21; FCD 38: Urk. IV, 665,13; 401,13; 405, 14; 4013,2.

${ }^{96}$ WB I, 166.1; Urk. IV, 637,12; FCD 38. It often is determined with the sign; and as a stone vessel.

${ }^{97}$ WB I, 97.12-98-6; i.e.: 3.t had.t, 3.t bi.t, 3.t rwd.t.

${ }^{98}$ WB IV, 77.10-11; MedWb 724, Anm. 5.

${ }^{99}$ WB III, 150.15; FCD 176. I.e. in the P.London BM EA 10477 (P.Nu), Tb 108: the text reads: 'iw hw,tntr.f $m$ Hrs, t' 'His temple was built of carnelian'. cf. The Online Internet Website: TLA: B. Backes, Totenbuch-Projekt, Ägyptologisches Seminar der Universität Bonn; G. Lapp, The Papyrus of Nu (BM EA 10477), Catalogue of Books of the Dead in the British Museum I (London, 1997), pl. 22-23. 
${ }^{100}$ WB V, 598, 10; Harris, Minerals, $139 \mathrm{f}$.

${ }^{101}$ Tylor-Griffith, The Tomb of Paheri at El Kab, (London, 1894), 18, pl. 4, upper right; W. C. Hayes, The Scepter of Egypt, II: The Hyksos Period and the New Kingdom, (Cambridge, 1959), 23. Also, imitation ostrich eggs were made of clay and marble and painted with various patterns. As well as the 'swh.t'-vessel which was made of half an ostrich eggshell. WB IV, 74.3; Hannig, Grosses Handwörterbuch ÄgyptischDeutsch, 680; E. Edel, Beiträge zu den Inschriften des Mittleren Reiches in den Gräbern der Qubbet el Hawa, MÄS 25 (1971), Abb.10 (4th column of the middle register).

${ }^{102}$ R. A. Caminos, LÄ I, 1186, s. v. 'Ei'; A. Lucas, Ancient Egyptian Materials and Industries, (London, 1962), 250; Ostrich eggs were also sometimes made into jewelry such as beads and pendants to be put on a chain and worn around the neck. Alcock, Food in the Ancient World, 75.

${ }^{103}$ W. Westendorf, 'Beiträge aus und zu den medizinischen Texten', ZÄS 92 (1966), 149.

104 WB IV, 71.1. It also defines 'the two sides of the coffin', and often contains circular signs as determinatives. Also, the last meaning brings to mind that the egg is a metaphor for the coffin.

${ }^{105} \mathrm{WB}$ IV, 71.1.

${ }^{106}$ WB IV, 77.10.

${ }^{107}$ WB IV, 77.9, cf. Pyr. 1343b.

${ }^{108}$ Westendorf, ZÄS 92, 149.

109 cf. $T b$ (Allen), 172, 3-4; see above.

110 I.e. $B M$ EA 10042 VI, 12 (Harris Magical Papyrus). A magical incantation for protection from crocodiles, by stating that he had emerged from the waters at creation as a companion of the sun God. This incantation, as well as several other magical incantations, is to be read on an egg made of clay that was to be thrown in the lake/river. Leitz, Magical and Medical Papyri of the New Kingdom, 39, Pl. 17 (12).

${ }^{111}$ WB II, 175.14; Compare with the similar inventory, WB II, 170,6 (mtpn.t, Dagger sheath).

${ }^{112}$ Pyr. 1840b: 'Osiris Neith, Take yourself the eye of Horus. mtpn.t cloth'. cf. also J. P. Allen, The Ancient Egyptian Pyramid Texts, Writings from the Ancient World 23 (Atlanta, 2005), Nt 204.

${ }^{113} W B \mathrm{~V}, 306.8$.

${ }^{114}$ WB II, 201.10. It is attested from the Greco-Roman Period. Otherwise, it may be derived from its preceding inventory in the Berlin dictionary $n j$, 'a newborn child'. WB II, 201.9. This suggests another possibility that it is giving the deceased the mythical possibility of rebirth as a newborn which also symbolically gives the significance of the egg to such fabric or wrapping. Compare also, the primeval water 'niw' (FCD 125), which resembles the egg. Perhaps, also, there is a sort of association (?) with the word 'niw' 'ostrich.' WB II, 202. 8; FCD 125; Pyr. 469; Urk. IV, 19, 10.

${ }^{115}$ WB IV, 334.2. The Berlin Dictionary put this word in comparison with the word 'str' 'a sweet thing', which also includes the egg sign determinative: $W B$ IV, 344.3 , see also above. 